\title{
Natural Food for Domestic Animals: Mini Review at International Level
}

\author{
Al-Farga Ammar* \\ Department of Biochemistry, Faculty of Science, University of Jeddah, Saudi Arabia \\ *Corresponding Author: Al-Farga Ammar, Department of Biochemistry, Faculty of \\ Science, University of Jeddah, Saudi Arabia
}

Received: March 26, 2020

Published: April 30, 2020

(C) All rights are reserved by Al-Farga Ammar.
During the second half of the twentieth century, as in all other scientific subjects, significant advances related to the domestic animal sector occurred especially. The significant developments in socioeconomic rates of individuals and their lifestyle have resulted in noticeable increases in the interest in pets. With the production of nutritious and advanced foods the domestic animal sector shows innovations. Lifetime pet foods must be nutritionally balanced and healthy $[1,2]$. Knowing the nutritional benefits of foods currently available is critically important in ensuring a balanced diet for dogs and cats to keep them safe [3]. In 2016, there were 89.7 million dogs in the United States, and 94.2 million cats [2]. While some government agencies have official definitions for the term natural, the natural pet food market has grown as demand for this sector is increasing, driven by the consumer's perception that these products are of high quality and nutritious and have practical health benefits, although there is little evidence for the impact of natural food on pet health [4]. The use of diet for health promotion and prevention of disease is not new but in recent years it has gained some attention. Interesting methods exist about the importance of functional foods in domestic animals [5-10]. Nevertheless, the effect of these foods on dogs and cats needs to be studied in order to better understand their metabolism and thus to improve the nutritional status and health of the domestic animal [3].

\section{Bibliography}

1. Baser Ö and Yalçin S. "Determination of some quality characteristics in pet foods". Ankara Üniversitesi Veteriner Fakültesi Dergisi 64.1 (2017): 21-24.

2. Viana Larissa., et al. "Natural food for domestic animals: A national and international technological review". Research in Veterinary Science 130 (2020): 11-18.

3. Di Cerbo A., et al. "Functional foods in pet nutrition: Focus on dogs and cats". Research in Veterinary Science 112 (2017): 161-166.
4. Buff PR., et al. "Natural pet food: A review of natural diets and their impact on canine and feline physiology". Journal of Animal Science 92.9 (2014): 3781-3791.

5. Canello S., et al. "Nutraceutical approach for struvite uroliths management in cats". International Journal of Applied Research in Veterinary Medicine 15 (2018): 19-25.

6. Di Cerbo A., et al. "Clinical evaluation of an antiinflammatory and antioxidant diet effect in 30 dogs affected by chronic otitis externa: preliminary results". Veterinary Research Communications 40.1 (2016): 29-38.

7. de Godoy MRC., et al. "Innovations in Canine and Feline Nutrition: Technologies for Food and Nutrition Assessment". Annual Review of Animal Biosciences 4 (2015): 311-333.

8. Di Cerbo A., et al. "Tetracyclines: Insights and Updates of their Use in Human and Animal Pathology and their Potential Toxicity". The Open Biochemistry Journal 14 (2019): 1-12.

9. Joffe DJ and Schlesinger DP. "Preliminary assessment of the risk of Salmonella infection in dogs fed raw chicken diets". Canadian Veterinary Journal 43.6 (2002): 441-442.

10. Sechi S., et al. "An Antioxidant Dietary Supplement Improves Brain-Derived Neurotrophic Factor Levels in Serum of Aged Dogs: Preliminary Results". Journal of Veterinary Medicine (2015): 412501.

\section{Assets from publication with us}

- Prompt Acknowledgement after receiving the article

- Thorough Double blinded peer review

- Rapid Publication

- Issue of Publication Certificate

- High visibility of your Published work

Website: www.actascientific.com/

Submit Article: www.actascientific.com/submission.php

Email us: editor@actascientific.com

Contact us: +919182824667 